\title{
VIOLENCE, LIBERATION AND THE LEGACY OF MODERNITY: TOWARDS A THEOLOGY OF PEACE
}

\author{
Mark Rathbone and Anné Verhoef \\ North West University \\ Potchefstroom
}

\begin{abstract}
Since the rise of democracy in South Africa violence has been erasing freedom and justice. In this article it is argued that the different theologies of Liberation, such as Black, Feminist, Ecological and other contextual theologies, might have perpetuated violence as part of the modernistic tradition they stood in. The irony is that the emancipatory motives of these theologies precipitate the oppression they are fighting. Theology therefore needs to revisit the modernist foundations of these theologies in a robust dialogue that challenges the limitations of modernity in order to discover emerging alternatives that nurture a theology of life, freedom and peace. David Hart proposes a theology where the theme of beauty, as essentially peace, adheres to every moment of the Christian story: A theology which celebrates a God whose being is beauty; whose works are an expression of his beauty; and in which the gospel is a story that persuades only by its beauty. This theology stands in contrast to the dichotomies of for example Black and African Theologies which are based on 'modernity's violent legacy' - a reductionistic ontology.
\end{abstract}

Key Words: Modernity, Black Theology, African Theology, Violence/Peace, David Hart, Reductionism

\section{Introduction}

In "revisiting and gathering various strands of contextual theology" we will briefly focus on Black and African theology in this article. It will, however, become clear that these contextual theologies are part of broader contexts, namely that of modernism (and postmodernism), and therefore it is not so easy to discern "a distinctly South African way of doing theology". ${ }^{1}$ In this article, we will begin with a description of modernism as the farewell to a theo-centric epistemology and the rejection of a theo-ontology, which lead to the construction of various reductionist dichotomies of which the result is one of ontological and epistemological violence. In other words, violence is a function of reductionism. This view of violence is distinct in Modern Theologies such as Liberation, Feminist and Black Theology that view violence as structural violence in terms of oppressive and hierarchical systems like globalisation, patriarchy and racism.

The dichotomies (and violence) as a dimension of modernity inform many theologies in the South African context and are visible in for example Black Theology and African Theology as the debate between Mbiti and Tutu demonstrates. This debate will be discussed in the second part of this article. In late modernity (or postmodernism) a wave of

\footnotetext{
The theme of the Theological Society of South Africa's annual meeting in June 2011 in Johannesburg was "A distinctly South African way of doing theology? Revisiting and gathering various strands of contextual theology".
} 
criticism against the construction of these reductionist dichotomies was raised mainly in the form of 'deconstruction'. The result of this criticism is the destabilisation of the epistemological and ontological assumptions of modernism. The third part of this article will thus look at an alternative to the "violent alienation of modernism" and discuss the theology of David Hart. Hart suggests as a 'postmodern' theologian an alternative ontology (and consequently alternative epistemology) to that of modernism and postmodernism alike and develops an ontology of peace that aims not to result in the dichotomies of modernity. This theology of Hart is based on the understanding of the Trinity as beauty and of creation as the overflow of this beauty. We argue in the conclusion of this article that there is much potential in doing theology from within this Trinitarian ontology. It is a theology completely committed to peace but with the ethical and critical cutting edge of exposing the inclination of reductionism of modern ontology in all its oppressive, racial, gender, colonial and other exploitative expressions.

\section{Modernism and Violence}

Modernism is a radical departure from a geo-centric cosmology, teleological ontology and theo-centric epistemology (Tarnas 1991:419). This departure introduces a dramatic shift in the history of the world that liberates humanity from determinism and ecclesial controlled cosmos - a renaissance that embraces life, its value, excitement and existential significance (Tarnas 1991:224). This liberation of humanity soon became a double-edged sword with violence as the price for freedom.

Modernity brought many changes to people's deepest convictions about themselves and the world they live in. The Copernican revolution transformed the idea that the earth and humanity, as the pride of creation, constitute the centre of the universe - leading to displacement, disenchantment with reality, loneliness and insecurity in a vast universe (Tarnas 1991:416). This liberated humanity from the scholastic Middle Ages and dogmatism, but, at the same time tore humanity from the 'cosmic womb' (Tarnas 1991:416). The dualistic ontology of Descartes is a dramatic liberation of the human self - distinct and separate from reality. Drawing from the new cosmology, he moved from a position of doubt to cogito (Tarnas 1991:417). In a lonely universe, humanity is the master of his or her fate with the freedom and power to influence. The subjectivity of the mind with its interpretations of reality presupposes a separation from reality. Knowledge is constructed, indirect and mediated - "knowledge of reality forever incommensurate with its goals..." (Tarnas 1991:417). Kant, building on the Cartesian cogito, produced the epistemological schism by waving farewell to a theo-centric epistemology. The mind does not reflect reality but renders a subjective or interpretative account of reality. Darwin later reinforced this by surrendering humanity to the "flux of evolution - no longer divinely ordained, no longer absolute and secure, no longer the crown of creation, the favoured child of the universe, but rather just one more ephemeral species" (Tarnas 1991:418). Humanity reduced to yet another species, but with the power to construct reality and produce results that satisfy their goals no matter what the consequences. Modernity's new ontology seems to create a notion of unrestricted freedom and power.

The freedom, liberty and power of modernism, however, came at a price because the perpetuation of violence that controlled reality and freedom during pre-Modernism is continuing in new forms. Taylor (2003:1-12), for example, identifies three dimensions where the violent disconnection from pre-modernity is present - individualism, instrumental reason and political apathy. Many regard individualism as the finest achievement of modern civilisation (Taylor 2003:2), but the right to choose and freedom 
from the "great chain of Being", has a flip-side. It also leads to 'disenchantment', lack of purpose and lack of passion - "...the dark side of individualism is a centring on the self, which both flattens and narrows our lives, makes them poorer in meaning, and less concerned with others or society" (Taylor 2003:4). Taking control meant constructing a stark, rigid and empty reality - a reality reduced to the limits of humanity subjectivism. An element that deepens the reductionism of reality is the priority of instrumental reason - cold and calculated rationality with a measure of success that focuses on maximum efficiency and the best cost-output (Taylor 2003:5). Instrumental reason as a function of individualism implements human constructions with zeal. Progress, mechanism, technology are key aspects leading to the 'iron cage' - enclosing humanity in market and state structures (Taylor 2003:8). These institutions and structures restrict choice, society accepting 'soft' despotism (Taylor 2003:9). As part of individualism, modernity's ontology is thus a 'rigid and empty' one and as part of instrumental reason it is an ontology of reductionism to a world of mechanism and technology. The consequence of this ontology is a world where humankind's freedom is violated, where humanity exists in an 'iron cage' of restriction, reductionism and of violence in many disguises. The violent alienation of modernism perpetuates violence in every aspect of society in the guise of freedom and equality. This is also clear in modern theologies, such as Liberation, Black, Feminist, and Ecological theologies in which certain dichotomies are constructed on the basis of modernity's ontology.

\section{Construction of Dichotomies}

Modernism thrives on the construction of dichotomies. The trace of these constructions goes back to the Cartesian object/subject dichotomy and later crystallised in the structuralism of Ferdinand de Saussure. Structuralism consists of a complex system of dichotomies - signifier/signified, synchronic/diachronic, denotation/connotation (Aichele 1997:24). The tension created by this duality resulted in an ontological revolution giving priority to the subject or cogito. This is a movement from the left hand side to the right hand side of the object/subject dichotomy - the modern mode and ethic of freedom. This leaning to the underside of the hierarchy is the mode of reality, knowledge, liberty and freedom of modernism. In the absence of a teleological motive, movement within the constructed dichotomies becomes the motivational force - rationally executed to produce liberty. The ethics of freedom is synonymous with this constructed reality. The problem is that it is a reduced reality imposing its dichotomies on reality. This perpetuates the same violence that tore humanity from the 'cosmic womb' in the transformation of premodernism to modernism. Jacques Derrida highlights the existence of this violence (as a reductionist construction of reality) in our language (as speech and writing).

Derrida (1976:11) refers to the modernist obsession with the cogito as logocentrism - a symptom of the speech/writing dichotomy of modernism. The priority of speech is located in its physical proximity to mental or cognitive processes. It represents a direct channel between thought and articulation. Writing is a secondary expression of thought, less trustworthy and more likely to be open to distortions. According to Derrida (1976:11), the priority given to speech is misleading because of the interdependence of speech and writing - speech is writing in oral form and vice versa. In other words, logocentrism disguises the violence of construction and reduction of reality. It serves power and ideology in the name of justice and liberty. Distortions and ambiguity are part of reality and no construction can do justice to its complexity. Constructions are preliminary - deconstructions. "The word 'de-construction' is closely related not to the word 'destruction' but to the word 'analysis', 
which etymologically means 'to undo'- a virtual synonym for 'to de-construct'. The deconstruction of a text does not proceed by random doubt or generalised scepticism, but by the careful teasing out of warring forces of significance within the text itself. If anything is destroyed in a deconstructive reading, it is not meaning but the claim to an unequivocal domination of one mode of signifying over another" (Derrida 1972:xiv). Derrida indicates that writing is an act of construction - reduction that severs parts of reality. It is an act of violence (domination/power) in humanity's attempt to represent the complexity of reality. This modern ontological impulse perpetuates violence in all the spheres of existence, if left to its own devices. Therefore, we acknowledge that our attempt at writing this article is a construction and implodes under the same pressure as all writing does, but with the difference that we acknowledge it and invite the moment of deconstruction.

The problem is that ontological (and cosmological and epistemological) reductionism violently forces complexities into a cognitive set or gestalt. This becomes visible in functional theologies that 'take control' of the human problems and fit novelties and paradoxes into stable systems - an act of violence against the complexity and diversity of reality and life (and also of theology). It is an act that limits human reason and the mystery of life. It abruptly suppresses in order to control and take charge. The problem is that this limiting activity places a restriction on creativity, progress and the freedom to explore. The ethical agenda of modern theology hides this violence of its modes. It seems thus that crime and corruption are far deeper than the legacy of apartheid or even colonialism in all its inhumane expressions, because they are inherent in the modern paradigm - democracy, liberty, nationalism, and everything that makes life complex today. For example: in South Africa, this is clearly visible in the way apartheid neo-colonialism made way for nationalism, elitism and totalitarianism, by perpetuating the poverty and suffering of people: "A new black elite has emerged in South Africa, mostly from the ranks of the liberation movement - people who were able to use their political pedigree and connections to amass vast amounts of wealth" (Mda 2004:8). Mda (2004) continues by warning that "while the national elite stuff themselves in these public displays one can already hear rumblings from the youths in the ghettos who feel left out". The elitism, greed and violence of modern institutions echo the disturbing effects of modernism that Taylor refers to narcissism, instrumentalism and fragmentation. ${ }^{2}$ We now turn to the articulation of these ontologies in modern theology.

\section{Modern Theology ${ }^{3}$}

Modern theologies, in many instances, embrace dichotomous ontologies and logocentrism to resist economic exploitation, globalisation, patriarchy, colonialism and other hegemonic systems, however, unintentionally repeating the same violence they are resisting. Submitting our analysis to the constraints of writing we acknowledge that these theologies are complex but we are of the opinion that, if these reductionist dichotomies are present,

2 This is not a surprise in the wake of the modernising educational enterprise in South Africa: "annals of schools, missions, universities, scholarly societies, hospitals in Asia, Africa, Latin America, Europe, and America are filled with this history, which over time established so-called modernizing trends..." (Said 1994:269). The question is whether there is an alternative to the modern ideology produced by universities and educational institutions in South Africa?

3 For the purpose of this article we specifically focus on contextual theologies and argue that they follow the modernism impulse at reductionism and dichotomous constructions. We acknowledge that because of the characteristics of defining it may be possible for some to view these theologies as postmodern. For us postmodernism is the implosion of modernism because of the Copernican turn that disregarded theo-ontology. 
this ethic is in danger of precipitating violence. The following examples represent traces of this violence: Latin American liberation theology constructs class dichotomies informed by Marxism (Gutierrez 1983; Boff 1987); Feminist theology constructs gender dichotomies (Schüssler-Fiorenza 1988); Black theology does the same in resisting white racism, opting for the articulation of black experience (Cone 1996); and the Western/non-western dichotomy is the basis of postcolonial theology (Sugirtharajah 1999). The same pattern is also present in ecological theologies, constructing a human/nature dichotomy.

The problem of this recurring pattern is that reality is constructed in terms of a reduced sense of class, gender, race, culture and environment. From this follows the construction of dichotomies with rigid boundaries - rich/poor, male/female, black/white, etcetera. This ignores the complexity of identity and the fluid range of possibilities between the binary oppositions. What remains is brutal categorisation and separation between the inside and outside of superficial, constructed identity. The violence of this ontology translates to physical reality with the imposition of these constructions on reality - an act of force. Schüssler-Fiorenza (1999:6) acknowledges the crudeness of this ontology with the concept wo/man that reflects the complexity of gender identity.

The failure to acknowledge the impact of reductionism results in ontological and epistemological violence - modernity becomes a pressure cooker that implodes under its own forces. Dichotomies such as white/black (Black Theology), male/female (Feminist Theology), humanity/creation (Ecological Theology) reflect this construction of power and violence in these modern theologies. The problem is that the dichotomies lead to particularities which result in a form of relativism that betrays the ethics of freedom by bracketing other dimensions of reality. The consequence of this is a frustrating and continuing movement to include excluded voices as an ethical imperative and this results in an absurd amalgamation of identities that forever remains temporary, incomplete and can even become crude. The attempt by Patte to respond to the challenges of feminism by introducing an androcentric perspective that emphasises the male experience in theological construction is an example of how innocently crudeness can arise (Patte 1995:25). Schüssler-Fiorenza (1999:8) states, "The politics of exclusion and silencing that has shaped the very ethos of the discipline is overlooked in Daniel Patte's response to the challenge of my Society of Biblical Literature's presidential address to the academy. Although the book is well intentioned and comes highly recommended, it does not grapple with the fact that kyriocentric ${ }^{4}$ Euro-American male-stream scholarships are part of the problem rather than part of the solution". The problem is Patte takes no cognisance of the left/right movement of modern ethics, from the experience of maleness to femaleness, as an act of resistance and power. To make matters worse, an attempt to be transparent and responsible results in multiple particularities that remain preliminary.

Reductionism is also an exclusionist strategy that encloses and excludes people that do not fit the criteria - violence of exclusion. The freedom promised by modern theologies results in a defensive position that requires violence to protect itself from exposure. This is evident in the rise of Black Theology in South Africa and the tension that developed with African Theology. Both these theologies are good examples of "the absurd amalgamation of identities" and the "violent exclusion of people" as a result of the created dichotomies.

Schüssler-Fiorenza (1999:8) defines kyriarchal/kyriocentric as follows: "derived from the Greek term for lord, this coinage underscores that domination is not simply a matter of patriarchal, gender-based dualism but of more comprehensive, interlocking, hierarchically ordered structures of domination, evident in a variety of oppressions, such as racism, poverty, heterosexism, and colonialism". 
These theologies will now be discussed as illustration of modernism's violent legacy, as a reductionist ontology which manifests itself in theology in the South African context.

\section{Black/White and African/Western Dichotomies in the South African Context}

Black Theology goes back to the civil rights - and later the Black Consciousness movement in the United States of America (Bosch 1979:221). Civil rights movements focus on modern values of the Renaissance - freedom, equality and justice. Black consciousness goes a step further as an articulation of modernism and the turn to the subject as a function of resistance of white on black racism. In this regard, Cone refers to the salient ideas of modernism in his definition of Black Theology: “...a rational study of the being of God in the world in light of the existential situation of an oppressed community, relating the forces of liberation to the essence of the gospel, which is Jesus Christ" (Cone 1996:1). Cone defines Black Theology as the embrace of rationality and the move of Descartes to the subject in terms of the black experience of racism and suffering - empowering black people and resisting white racism. Black Theology argues that traditional theological discourse reduces theology to a white discourse of oppression. "Black theology, therefore, is that theology which arises out of the need to articulate the religious significance of [the] Black presence in a hostile White world. It is Black people reflecting on the Black experience under the guidance of the Holy Spirit, attempting to redefine the relevance of the Christian gospel for their lives" (Antonio 1999:65).

In South Africa, these ideas had a major impact in the struggle against apartheid. They gave black people who experienced the breakdown of their self-esteem and worth under apartheid a sense of pride and purpose. They also became a motive for political résistance and: "Theologically speaking, blacks must take this responsibility and formulate in their own words their belief in God. They can no longer hide behind the theological formulas created by someone else" (Boesak 1977:12-13). What is interesting in Boesak's position is that it also represents a radical departure from the perspective of Cone. Boesak $(1977: 16)$ proposes that: “...it is the Word of God which illuminates the reflection and guides the action". Boesak's (1977:16) fear is that "Cone attaches too much theological importance to the black experience and the black situation as if these realities within themselves have revelational value on a par with Scripture". Boesak (1977:16) states: "God, it seems to us, reveals Himself in the situation, the Word is being heard in the situation, thereby giving meaning to the situation. The black experience provides the framework within which blacks understand the revelation of God in Jesus Christ". It is at this point that Boesak (1977:112) links Black Theology with Liberation Theology arguing that the "will of God" is "liberating the oppressed". Boesak (1977:113) states: "Indeed, Black Theology is a theology of liberation in the situation of blackness. For blacks, it is the only legitimate way of theologising - but only within the framework of the theology of liberation". Boesak introduces the Bible as critical criterion to avoid the trap of radical subjectivity and reductionism, but then reduces the Bible to a theology of liberation. Desmond Tutu (1983) follows a similar line of argument as Boesak but gives greater prominence to the African cultural framework of ubuntu - "Ubuntu is very difficult to render into a Western language. It speaks of the very essence of being human. When we want to give high praise to someone we say, 'Yu, u nobuntu'; 'Hey, he or she has ubuntu'. This means they are generous, hospitable, friendly, caring and compassionate" (Tutu 1999:34). Battle (1996:101) states that ubuntu "disallows false dichotomies of Black and White people" (Battle 1996:101). The question is whether reductionism of modern ontology allows such a smooth opening of the white/black dichotomy? 
Mosala (1993) and Mofokeng (1985) severely criticised the theology of Boesak and Tutu for their uncritical use of the Bible. The Bible contains inscribed ideologies of race and class that are open to criticism: "Thus the black experience of oppression and exploitation provides the epistemological lens through which to perceive the God of the Bible as the God of liberation... Paradoxically, black theology's notion of the Bible as the Word of God carries the implication that there is such a thing as a non-ideological appropriation of Scripture. Black theologians condemn white people's view of God and Jesus Christ as apolitical, that is, above ideologies, on the one hand; but they maintain a view of Scripture as the absolute, non-ideological Word of God that can be made ideological only by being applied to the situation of oppression, on the other hand" (Mosala 1993:53). Mosala and Mofokeng give priority to black experience as the critical dimension of Black Theology.

Two modes of Black Theology operate in South Africa with a common reference to the subject - black experience of racism under apartheid. Boesak and Tutu represent a strand of Black Theology that qualifies subjectivity in terms of the Bible and a theology of liberation. On the other hand, Mosala and Mofokeng, although informed by Marxist critical theory, follow a more radical route with black experience as critical criterion of Black Theology. Both of these perspectives, informed by modern ontology, reduce the concept of blackness and fail to acknowledge the complexity of black experience in terms of other categories such as gender, colonialism, economics and culture; although Tutu's concept of ubuntu is an improvement, it remains entrenched in modernism. It perpetuates ontological reductionism through the construction of rigid dichotomies. The danger (and violence) of this reductionism is clear in the debate between Tutu and Mbiti about the identities and categories of 'black' and 'African', with Mbiti fervently rejecting the role of Black Theology.

\section{Debate between Tutu and Mbiti}

Mbiti (1979:477-478) views Black Theology as a reactionary theology that grew from the churches' failure to resist the injustice of slavery. It has a context of suffering, sorrow and anger and is an embarrassment to Christianity in the USA. The problem is the primacy of racial categories. Mbiti (1979:478) writes: “One such concern is 'blackness' itself. It wants to see 'blackness' in everything. It speaks of a Black God, Black Church and Black Liberation, Black this and Black that...It is necessary to remind oneself that racial colour is not a theological concept in the Scriptures". Blackness has become an "ideology embracing much of life and thinking of Negroes in America, whether their skin colour is black, dark brown, light brown, khaki or coffee, or even if they have a remote African ancestry and most of their biological heritage is actually French, English, Scottish, American Indian or other. All are "black"” (Mbiti 1979:479).

Mbiti (1979:479) is not only critical about Black Theology, but also about the view that the Bible is a book of liberation. To him, this is a limiting view: "When the immediate concerns of liberation are realised, it is not at all clear where Black Theology is supposed to go. Black Theology is deeply 'eschatological', yet its eschatological hopes are not clearly defined. There is no clue as to when one arrives at the paradise of "liberation". Mbiti (1979:481) concludes that Black Theology cannot and will not become African Theology. African Theology arises from the joy of the experience of Christian faith, it is not restrictive in concerns, nor is it an ideology and it is concerned with Africa and the problems and joys of Africa (Mbiti 1979:481-482). "African Theology has no interest in colouring God or 
Christ black, no interest in reading liberation into every text, no interest in telling people to think or act "black"' (Mbiti 1979:482).

In his response, Tutu (1979:484-485) argues (as a defence for Black Theology) that there are unquestionable links between the Blacks in the United States of America and 'South' Africa, namely: skin; the bond with Africa, and the colonial racism; both were baptised and are part of the body of Christ. This implies that black people are compelled to help the whites to correct many of the distortions that have happened to the gospel to the detriment of all.

Tutu (1979:487) emphasises that there are similarities between Black - and African theologies in an attempt to emphasise the role of Black Theology: Firstly, African hermeneutics resists Eurocentric Christian cultural discourse by reading the Bible from the African cultural matrix. In the USA, the same process is present where Black people read the Bible from the cultural matrix of Black culture to resist White essentialist reductions. So, both promote the humanness and agency of Black people. ${ }^{5}$ Secondly, both are a theological critique of Western universalism and essentialism. Both develop a contextual hermeneutic traced back to Africa. Black Theology is also a criticism of the placid nature of African Theology that focuses on 'anthropological concerns'. African Theology needs the 'existential urgency' of Black Theology. The explicit political dimension of Black Theology provides this, especially in the South African context. ${ }^{6}$ African Theology, according to Tutu (1979:490), has lost its cutting edge because it remains ignorant of ethical and political issues concerning Africa such as poverty, military coups and health. This can change, according to Tutu (1979:490), only when a radical spiritual decolonisation occurs within each exponent of African theology that unravels the notion that a Western value system and categories are of universal validity.

Tutu emphasises the priority of the role of the white/black dichotomy as a mode of resistance to racism. In this process black experience and its articulation balance the dichotomy. The emphasis is on the black underside of the hierarchy - igniting the ethic of liberation. The absence of this process from African theology perpetuates white racism, according to Tutu. The problem is that Tutu winds his theology up in an ontological paradox - attempting to incorporate an African holistic ontology in terms of his use of the concept $u$ buntu into a modern atomistic ontology. Mbiti is suspicious of the construction of the dichotomy because of its reduction of African culture. The reductionism of African Theology though exclusive racial categories does violence to the complexity of African culture. Black Theology becomes a function of cultural alienation that commits ontological and epistemological violence in the name of liberty, equality and justice.

The problem with the inclusion of African culture in the white/black dichotomy is that an African/non-African dichotomy is added - constructing yet another reductionism with exclusivist impulses. Haddad (1996:207) asks the question whether "African theology...has

Tutu writes (1979:487): "They stake the claim for the personhood and humanity of the African and AfroAmerican, for anything less than this is blasphemy against God who created us as we are in His own image, not to be carbon copies of others of His creatures no matter how advanced and prosperous they might conceive themselves to be".

6 Tutu (1979:490) states: "I myself believe I am an exponent of Black Theology coming as I do from South Africa. I also believe I am an exponent of African Theology coming as I do from Africa. I contend that Black Theology is like the inner and smaller circle in a series of concentric circles...I and others from South Africa do Black Theology, which is for us, at this point, African theology".

7 Tutu challenges African hermeneutics to move beyond the comparative method and be African by embracing the wholeness of being, humanity, transcendence and the spirit of Africa - ubuntu (Tutu 1979:491). 
fallen into the trap of idolising African culture in an uncritical way...". Maluleke (2000:9495) agrees by stating that "...there cannot and should not be such a thing as "African Biblical Scholarship' if this is envisaged in terms akin to that produced by Western-type training". He insists that their relationship to the Bible is "part of a larger package of resources and legacies which include stories, preaching and language mannerisms, songs, choruses, ecclesiologies, theodicies, catechism manuals and a range of rituals and rites" (Maluleke 2000:95). Although critical of Tutu, Mbiti's theology also reveals traces of reductionism and atomism.

The debate between Black and African Theology (Tutu and Mbiti) provides a clear illustration of the role of modern ontological violence using reductionist dichotomies, as it manifests itself in dichotomies in the South African context and of its un/intended consequences. Our question is what is the alternative to modernity's ontology (and consequent theologies)?

\section{David Hart as Holistic Theologian ${ }^{8}$}

David Bentley Hart's theology can in many ways be regarded as an alternative to the modernistic type of theologies that have been discussed so far. Hart is an Eastern Orthodox American theologian whose first book, The beauty of the infinite: The aesthetics of Christian truth $(2003)^{9}$ will be our main focus. Hart incorporates the thoughts of Milbank, Gregory and Von Balthasar ${ }^{10}$ in his very well-structured theology in which he shows that modern and postmodern philosophies remain captive to age-old dialectics that show their dependence on a master story that requires an ontology of violence. For Hart the Christian good news is, however, that it "offers an ontology of peace where the unity and difference in creation is embraced in the triune God made known in Jesus Christ" (Dewey 2005:224). This is Hart's book's (and theology's) main thesis. David Aers describes Hart's book as "a work of Milbankian scope, mood and erudition. A profound critique on the ontological assumptions of postmodernity, grounded in violence, is followed by a Christian theology of beauty and the infinite" (2007:89).

Hart says that "an 'aesthetic' response to a postmodern insistence on the inescapability of violence is adequate only if it gives a coherent account of beauty within the Christian tradition itself; only if beauty belongs to the Christian narrative, fully and consistently developed... only if the theme of beauty, as essentially peace, adheres to every moment of the Christian story..." (2003:4). Hart set himself this task and says it is just such a "continuous theological account of beauty" that he wants to explore in his book. Central to his argument is that "the Christian infinite belongs to an ontology of original and ultimate peace, and as a consequence

8 Hart's theology is described here as holistic in the sense that his theology is a reaction to the reductionism and violence of modernity and postmodernity (for his discussion of these terms see Hart (2003:6-7).

9 This is a much revised version of his Ph.D. dissertation which he obtained from the University of Virginia.

10 Morrison says for example: “....his [Hart's] Orthodox tradition colors much in the book, beginning with the title. Gregory of Nyssa's theology lies behind and at the forefront of much of what Hart develops (Augustine and H von Balthasar taking prominent roles as well)" (2007:662). Placher (2004) gives a good overview of the influences of these different thinkers on Hart. From Milbank, Hart takes up the notion that Christianity cannot prove its case, but must and can offer a rhetoric of peace in contrast with our age's dominant Nietzschean rhetoric of violence. That both God and creatures, in radically different ways, are inspired by love and beauty, is what Hart takes over from Gregory as well as Gregory's thoughts about the Trinity. Balthasar makes the case that theology begins with the aesthetic appreciation of God and Hart follows this point by structuring his work as theological aesthetics - as an exploration into the true beauty of the infinite triune God. Hart's whole project is, as his subtitle notes, an "aesthetics of Christian truth." 
allows a construal of beauty and peace inconceivable in terms of the ontology that Christian thought encounters first in various schools of pagan metaphysics, and encounters again in the thought of Nietzsche and his heirs" (Hart 2003:4-5). ${ }^{11}$

In his theology Hart tells the story of being in Western thought and exposes the inconsistencies and inadequacies of postmodernism as "the violence of metaphysics and the metaphysics of violence" (Hart, 2003:35). Hart launches here a critical history of Western philosophy and its recurrent failure to allow itself to be opened up by the Christian interruption. ${ }^{12}$ Oleg Bychkov says that Hart "presents a scathing critique of postmodern Nietzsche-style 'nihilism', in particular of the idea that violence and strife form the true foundation of reality" (2005:663). Hart tells the Western story of being in order "to remember something western thought has labored busily to forget: the intrusion of Christianity into that story, and the vision of reality the intrusion enables" (Jenson 2005:236). Hart's critique on postmodernism and modernism alike, thus prepares the ground for the idea that the foundation of the world is peace, rather than strife and that this peace (beauty) can be found in the Christian story. As a story next to those of the postmodernists Hart is aware that "there is nothing... that makes either perspective selfevidently more correct than the other" (2003:103) and therefore sees the need to base his perspective on aesthetic grounds as a counter-rhetoric.

Hart presents his theology as a dogmatic minora under the title "The Beauty of the Infinite" - a theology which can be described as an aesthetic confession of the beauty of the truly infinite God in which Hart gives a reflection on the four major themes of the authoritative Nicene-Constantinopolitan Creed, namely the Trinity, creation, salvation and the eschaton. In a poetic style (or more like a hymn - in contrast to the cold rationality of modernity) Hart develops a larger Christian narrative of the triune God's reconciling love in Christ, of the peace in the Christian evangel, as a rhetorical answer to postmodern violence. The beautiful truth of the "infinite glory of God found in the perichoretic relations" (Morrison 2007:664) of the Trinity is made central by Hart. The Trinitarian perichoresis is the life of the divine persons of eternal mutual self-donation and self-reception, which 'unnecessarily' overflows as the act of creation and brings home the creatures in salvation. In the Trinity the relations of difference between the persons of the Trinity are (as part of its perichoresis $^{13}$ intrinsically peaceful and therefore the Trinity constitutes thus the aboriginal peace. The Trinity as the foundation of everything, including reality, shows thus that the true form of difference and distance is peace. In the divine and "aboriginal ontology, therefore, difference is peaceful, not conflictual, and distance allows communion rather than entailing separation" (Wainwright 2004:36). Hart can say now that creation is divine glory, told anew, and so its aesthetic variety is nothing but the different modes and degrees with which participated being is imparted. Hart $(2003: 274)$ says, "As God is Trinity, in whom all difference is possessed as perfect peace and unity, the divine life might

11 Beauty and infinite play a crucial role in Hart's theology: "God's infinity is not formlessness but rather the beauty of a boundless agape, eternally and freely shared within the Trinity. This beauty - this exceeding weight of glory (kabod) - is displayed in the creation, which God brings into being without any 'need' to do so" (Wainwright 2004:36).

12 Hart discusses and finds philosophers such as Foucault, Derrida, Lyotard, Deleuze and Levinas massively wrong in their respective accounts of being - their ontologies left no room for the story (and reality) of Jesus Christ.

13 Hart says that the Christian understanding of beauty (and we can say peace here as well) is something which "emerges not only naturally, but necessarily, from the Christian understanding of God as a perichoresis of love, a dynamic co-inherence of the three divine persons, whose life is eternally one of shared regard, delight, fellowship, feasting, and joy" (Hart 2003:155). 
be described as infinite music, and creation too might be described as a music whose intervals, transitions, and phrases are embraced within God's eternal, triune polyphony". Hart presents thus the distance between God and creature not in terms of a formless inaccessible negation of the sublime, but in terms of the beautiful as an endless harmonious play (Hart 2003:188). ${ }^{14}$ Salvation, in this scheme of Hart, is then that which Christ brings "his incarnation repeats the divine gift of creation; his life and death render the perfect human response; his resurrection inaugurates a new world, the true world restored to itself" (Wainwright 2004:37).

Hart returns to the philosophical attack he started with in the first part of his theology and takes another look at his initial question: is the nature of all rhetoric violent or can there be peaceful (Christian) rhetoric? Hart notes that his whole book/theology has been an exercise in persuasion, in rhetoric. Jenson $(2005: 237)$ adds that it "must be, for it celebrates a God whose being is his beauty, and whose works ad extra are therefore expressions of his beauty, and so do not construct a proof but endlessly vary an attraction. Specifically the gospel is a story that persuades only by its beauty". The question remains, however, if this is not an attempt to create a new metanarrative with no room for other stories. Hart denies this by saying that the "Christian theology can only say it sees freedom from metanarratives precisely in the space between stories each of which is free to persuade" (Jenson 2005:237). ${ }^{15}$

\section{Hart's Ontology and Modernism's Dichotomies}

This article began with a description of modernism as the farewell to a theo-centric epistemology and the rejection of a theo-ontology. Within the new Cartesian ontology constructions of various dichotomies (white/black, male/female, and humanity/creation) were made. Reality was violently reduced to these dichotomies and even theologies were influenced by this Particularism and reductionism - the violent legacy of modernism - in its attempt to celebrate modern cultural values such as freedom, equality and rationalism. These dichotomies (and violence) of modernity are visible in for example Black Theology and African Theology as the debate between Mbiti and Tutu demonstrated. In his theology, Hart questions the epistemological and ontological assumptions of modernity (and postmodernity) and suggests an alternative ontology to allow for a theology that is more comprehensive and fundamentally peaceful.

In Hart's theology we find thus a theology that is primarily concerned with peace. Hart's understanding of modernity and postmodernity is that their ontology is necessarily one of violence. For Hart the 'self-evident' truths of modernity (for example that all men are created equal) and postmodernity's truth (that truth is to be decided only as a struggle among competing powers), are both part of the same narrative: "one that finds the grammar of violence inscribed upon the foundation stone of every institution and hidden within the

14 Bychkov (2005:665) says Hart sees the divine "interval not as being distant but as a musical interval where what is removed is inseparable from its counterpart, and even painful dissonance forms part of the harmony".

15 Hart's answer appears to be "some kind of benign permissiveness of all discourses" (Bychkov 2005:666), "a peaceful pluralism, where no voice is suppressed..." (Hart 2003:424), but there is no complete acceptance of modernity's pluralism by Hart. He effectively deconstructs the "deceptively benign hermeneutics of pluralism that... has in fact, its own clandestine master narrative ('the story of no stories'), its own metaphysical assumptions ('the truth of no truths') that sets limits to the claim of other narratives" (Wainwright 2004:38). The implication is thus that other master narratives must (at least in part) be defeated by the Christian story. Is this possible for Christians without violence, peacefully? Hart says it is possible because its persuasion is finally the acceptance even of its rejection, the gift of martyrdom that cannot be returned. 
syntax of every rhetoric" (Hart 2003:2). The 'foundation stone' needs thus to be replaced and that is what Hart set himself to do in proposing the narrative (a rhetoric of beauty) that "claims that within history a way of reconciliation has been opened up that leads beyond, and ultimately overcomes, all violence" (Hart 2003:2).

The only possible peaceful ontology, the only alternative to the violent ontology of modernism and postmodernism alike, is for Hart the one that is found in the triune God made known in Jesus Christ. The Christian good news is that it offers an ontology of peace where the unity and difference in creation are embraced in the Trinity. The Trinity is of vital importance for Hart, because it is as Father, Son and Spirit in their mutual relations, that we find true beauty and peace. The "beauty of the infinite" means that the Trinity has a shape, a formed infinity (unlike the infinity of the Nietzscheans) and that formed infinity is beauty. It is with this infinite beauty where our thoughts should begin, because this is where reality (our existence itself) begins and where it finds its unity and difference - true peace. ${ }^{16}$ Hart (2003:178) says, "the Christian understanding of difference and distance is shaped by the doctrine of the Trinity, where theology finds that the true form of difference is peace, of distance beauty." In contrast, Western thought's pairing of absolute and immanent within the 'metaphysics', difference (of which the postmodernists speak), can only be violent, because "the absolute stands to the finite as a formless and therefore alien infinity, against which the finite must defend itself" (Jenson 2005:236). On the other hand, in Hart's understanding of the Trinity as 'infinite beauty', we find that the Trinity constitutes the aboriginal peace and because of its perichoresis God's peace and beauty 'overflows' as the act of creation. For Hart, the Trinity as the Creator, in his beauteous apatheia, ${ }^{17}$ simply "passes by all apparently violent opposition. Perhaps one might say, the triune God is within his utter unity with himself so different from himself that he simply enfolds all such lesser differences as Western thought otherwise worries about. Just so, if he creates, his creatures' difference from him is not opposition but endlessly proliferating analogy, so that the true being of the creatures also is their reflected beauty. Being itself is musical, sequential, rhetorical" (Jenson 2005:236). Hart shows thus that the Trinity understood as a perichoresis of love of "eternal and mutual divine life establishes an ontology of peace, where difference is not cause to divide and conquer, but unify an established shalom" (Dewey 2005:225). The true form of the world, reality, is peace. The world God created was made for peace, not violence, and so violence is always a distortion of the true nature of things.

Hart's "aesthetics of the Christian truth" can thus be a way of doing theology that is more comprehensive in its hermeneutics (as Maluleke pleads for) and which can be an alternative to the modernists' violent theologies. It is a theology which ontology allows for difference that is peaceful, not 'conflictual', and for distance it allows communion rather than entailing separation. It is the acceptance of the idea that the true form of difference and distance is peace (Hart 2003:178). It is also a theology positioned against modern concerns

16 For Hart creation and the Trinity are thus intimately connected: "God's gracious action in creation belongs from the first to that delight, pleasure, and regard that the Trinity enjoys from eternity, as an outward and unnecessary expression of that love; and thus creation must be received before all else as gift and beauty" (Hart 2003:249).

17 Apatheia can be described here as God's love that because it is infinite is unaffected even by the events of its own out-pouring. It involves thus the doctrine that the divine nature is beyond suffering and change, but it is not a complete static or unchangeable God that is described with it. Rather, within the Trinity "God keeps overflowing in mutual love: God's impassibility is the utter fullness of an infinite dynamism" (Placher 2004:43). Hart (2003:256) compares it with true freedom: "ontological freedom or apatheia - is the perfect and unimpeded fullness with which the divine nature is itself, with which God is God...". 
for truth as such, for cold rationality. Hart is clear that "beauty rather than simply (only?) truth, or rather beauty as inseparable from truth, is the measure of that which theology may speak of as truly Christian" (Morrison 2007:663).

\section{Conclusion}

Certain theologies can clearly be identified as part of the modernistic era - an era of trust in the human subject and rationality, but also an era of physical and rhetorical violence. With the modernistic era imploding into postmodernism, creating new questions and a new context of doing theology, it is important to develop a theology that will not repeat the violence of modernism. The strength of Hart's theology is his attempt to move away from the rationality, dichotomies and the Cartesian cogito of modernity to an ontology of peace, unity and beauty. It is an effort to embrace the diversities and complexities of life and reality in their fullness (or beauty) instead of repeating the reductionism of modernism.

Hart's optimistic ontology enhances complexity but with the ethical cutting edge to deal with the injustice perpetuated by reductionism. In other words, the reductionism of oppressive constructions and dichotomies stimulates the critical impulse in terms of the beauty and peace of the Trinity. It is clear from the debate between Tutu and Mbiti that blackness does not respect the beauty of humanity because it reduces the fullness of human complexity. This stimulates criticism in terms of the reduction of humanity through this act of ontological violence. Hart's emphasis on peace is not only relevant for Africa, but his emphasis on God's beauty is also something that can find more accord with the African context than the harsh rationality of modernism. His theology emphasises a more holistic liberation, not based on dichotomies, but on the beauty and peace of the Trinity. It is an ontology that allows thus for much more complexity and diversity and it is therefore of huge value for the further development of 'modernistic' concepts such as freedom and equality. Hart's theology is thus not 'utopian' in its scope, but a fundamental and holistic focus on peace, beauty and unity within the world in which we live. Although his theology is not without criticism, ${ }^{18}$ it does provide stimulus for considering the critical role of a holistic ontology as alternative to reductionism.

18 Hart's theology is not without critique and some of it must be mentioned here although it will not be discussed in detail. One question is if Hart succeeds in describing the triune Creator as the one in which all oppositions finite and infinite, transcendence and immanence, absolute and relative - are united and at peace. Hart builds a strong argument that because God is triune he is in himself both distance and intimacy, love and selfdetermination, but this remains very difficult to comprehend. How is God's immanence then to be understood? And how then must we understand the distance between God and creation? Two more points of critique (which Jenson for example also mentions) are Hart's insistence on divine apatheia as well as his distinction between the "economic Trinity" and the "immanent Trinity". The problem is that Hart "envisions a God whose serenity simply is what it is, and who manifests his glory in the death and Resurrection of Christ but does not constitute it in them. Is this the way Scripture in fact tells its story of God?" (Jenson 2005:237). Jenson also raises questions about God's time and eternity in Hart's theology - a critique that needs more space to be discussed in detail. 


\section{BIBLIOGRAPHY}

Aers, D 2007. The beauty of the infinite: A question from the margin. Theology Today, 64:1, 89-95.

Aichele, G 1997. Sign, Text, Scripture: Semiotics and the Bible. Sheffield: Sheffield Academic Press.

Antonio, E 1999. Black Theology. In: Rowland, C (ed.) 1999. The Cambridge Companion to Liberation Theology. Cambridge: Cambridge University Press.

Battle, M 1996. The Ubuntu theology of Desmond Tutu. In: Hulley, L; Kretzchmar, L \& Pato, LL (eds.). 1996. Archbishop Tutu: Prophetic Witness in South Africa. Cape Town: Human \& Rousseau.

Boesak, A 1977. Farewell to Innocence: A social-ethical study of black theology and black power. Johannesburg: Ravan Press.

Boff, C 1987. Theology and praxis: Epistemological Foundations. New York: Orbis Books.

Bosch, DJ 1979. Currents and Crosscurrents in South African Black Theology. In: Wilmore, GS \& Cone JH (eds.) 1979. Black Theology: A Documentary History, 1966-1979. New York: Orbis Books.

Bychkov, O 2005. The beauty of the infinite: The aesthetics of Christian truth. Modern Theology, 21:4, 663-666.

Cone, JH 1996. A Black theology of Liberation: Twentieth Anniversary Edition. New York: Orbis Books.

Derrida, J 1972. Dissemination. Trans. Barbara Johnson. Chicago: University of Chicago Press.

Derrida, J 1976. Of Grammatology (Translated by Gayatri Chakravorty Spivak from De la Grammatologie, 1967) Baltimore and London: The Johns Hopkins University Press.

Dewey, BR 2005. The beauty of the infinite: The aesthetics of Christian truth. Perspectives in Religious Studies, 32:2, 222-225.

Gutierrez, G 1983. The Power of the Poor in History. New York: Orbis Books.

Haddad, B 1996. En-gendering a theology of development: Raising some preliminary issues. In: Hulley, L; Kretzchmar, L \& Pato, LL (eds.). 1996. Archbishop Tutu: Prophetic Witness in South Africa. Cape Town: Human \& Rousseau.

Hart, DB 2003. The beauty of the infinite: The aesthetics of Christian truth. Grand Rapids: WB Eerdmans.

Jenson, RW 2005. Review Essay: David Bentley Hart, The beauty of the infinite: The aesthetics of Christian truth. Pro Ecclesia, 14:2, 235-237.

Maluleke, TS 2000. The Bible among African Christians: A Missiological Perspective. In: Okure, T (ed.) 2000. To Cast Fire upon the Earth: Bible and Mission Collaborating in Today's Multicultural Global Context. Pietermaritzburg: Cluster.

Mbiti, J 1979. Black Theology/African Theology - Soul mated or Antagonists? Part 1. In: Wilmore, GS \& Cone, JH (eds.) 1979. Black Theology: A Documentary History, 1966-1979. New York: Orbis Books. 
Mda, Z 2004. Suffering in the wake of black empowerment. This Day, Wednesday 28 April 2004, 8.

Mofokeng, TA 1985. Reconciliation and Freedom. In: De Gruchy, JW (ed.) 1985. Cry Freedom: Prayers, meditations and readings from South Africa. Cape Town: Collins.

Morrison, JD 2007. The beauty of the infinite: The aesthetics of Christian truth. Journal of the Evangelical Theological Society, 50:3, 662-665.

Mosala, IJ 1993. Biblical Hermeneutics and Black Theology in South Africa: The use of the Bible. In: Gottwald, NK \& Horsley, RA (eds.) 1993. The Bible and Liberation: Political and Social Hermeneutics. New York: Orbis Books.

Patte, D 1995. Ethics of Biblical Interpretation: A Re-evaluation. Westminster: John Knox Press.

Placher, WC 2004. The aesthetics of faith: God's beauty. Christian Century, 121:18, 42-45.

Said, EW 1994. Culture and imperialism. London: Vintage.

Schüssler-Fiorenza, E 1988. The Ethics of Biblical Interpretation: Decentering Biblical Scholarship. Journal of Biblical Literature, 107:1, 3-17.

Schüssler-Fiorenza, E 1999. Rhetoric and Ethic: The Politics of Biblical Studies. Minneapolis: Fortress Press.

Sugirtharajah, RS 1999. Asian Biblical Hermeneutics and Postcolonialism: Contesting the Interpretations. Sheffield: Sheffield Academic Press.

Tarnas, R 1991. The Passion of the Western Mind. Understanding the Ideas that have shaped our world view. New York: Ballantine Books.

Taylor, C 2003. The ethics of Authenticity. Harvard University Press. London: England.

Tutu, D 1979. Black Theology/African Theology - Soul mates or Antagonists? Part 2. Wilmore, GS \& Cone, JH (eds.) 1979. Black Theology: A Documentary History, 1966-1979. New York: Orbis Books.

Tutu, D 1983. Christianity and apartheid. In: De Gruchy, JW \& Villa-Vicencio, C (eds.). Apartheid is a heresy. John Cape Town: David Philip.

Tutu, D 1999. No future without forgiveness. Johannesburg: Rider.

Wainwright, G 2004. The beauty of the infinite: The aesthetics of Christian truth. First Things, 141, 36-39. 